University of Chicago Law School

Chicago Unbound

Journal Articles

Faculty Scholarship

2004

\title{
McConnell v. Federal Election Commission: A Deadly Dose of Double Deference
}

Richard A. Epstein

Follow this and additional works at: https://chicagounbound.uchicago.edu/journal_articles

Part of the Law Commons

\section{Recommended Citation}

Richard A. Epstein, "McConnell v. Federal Election Commission: A Deadly Dose of Double Deference," 3 Election Law Journal 231 (2004).

This Article is brought to you for free and open access by the Faculty Scholarship at Chicago Unbound. It has been accepted for inclusion in Journal Articles by an authorized administrator of Chicago Unbound. For more information, please contact unbound@law.uchicago.edu. 


\title{
McConnell v. Federal Election Commission: A Deadly Dose of Double Deference
}

\author{
RICHARD A. EPSTEIN
}

T HE RECENT Supreme Court decision in McConnell v. Federal Election Commission ${ }^{1}$ marks yet another backward step in the march of constitutional law. As everyone already knows, the bottom line in McConnell was that Congress has a free hand to regulate what it perceives to be the pernicious influence of money on electoral politics. The control of corruption and the appearance of corruption in federal elections are both valid governmental interests. Armed with that vast insight, the five member majority upheld the two key provisions of the Bipartisan-read: Incumbent Protection-Campaign Reform Act (BCRA) that places limitations on the amount of soft-money contributions $^{2}$ to political parties and that limits the amount of advertising that may be done by and on behalf of political parties within 30 or 60 days of an election. ${ }^{3}$ The BCRA contains some mind-numbing detail that promises to provide full employment to the next generation of election lawyers. But it takes far less ingenuity to see why this new and powerful system of direct regulation on speech deserved an instant and merciless repudiation by the Supreme Court. Elections count as among the most important and distinctive activities of any

Richard A. Epstein is James Parker Hall Distinguished Service Professor of Law, The University of Chicago, and Peter and Kirsten Bedford Senior Fellow, The Hoover Institution. I should like to thank Pamela Karlan for talking through some of these issues, and Eric Murphy for his usual stellar research asistance. democratic society. The dense network of regulations under the BCRA imposes a manifest limitation on the ability of individuals to speak for themselves or to contribute to the war chests of others who are prepared to speak on their behalf. The upshot is less political speech.

The key question in these cases is what justification Congress can offer on behalf of this massive regulatory system. The success or failure of that justificatory exercise depends critically on the level of scrutiny that the Court brings to the central provisions of the BCRA. Before McConnell, it appeared-past tense-as though constitutional scrutiny, like Gaul, was divided into three parts. The highest standard of strict scrutiny was routinely applied to political speech necessary for the preservation of democratic institutions. The "compelling state interest" test demanded the identification of an imperative social end coupled with the selection of means tightly calculated to achieve that end. Overregulation was a fatal constitutional infirmity. Next in the pecking order was intermediate scrutiny, which called, roughly speak-

\footnotetext{
1124 S. Ct. 619 (2003).

2 Under the Federal Election Campaign Act of 1976, contributions to parties were limited only if used for specific endorsements of particular candidates. Funds received within these limits are hard money. Under the BCRA, all contributions to national parties must be hard money, whatever they are to be used for, and the application of the federal restrictions to state and local parties is greatly expanded.

${ }^{3}$ Section 323(b).
} 
ing, for a solid connection between important social ends selected and the means chosen to achieve them. Hence, this test leaves somewhat more "give" on both the ends and means dimensions of scrutiny. Last, and lamest, in the constitutional firmament was the (mis)named rational basis test, which routinely sustains economic regulation for which the state can supply a convenient fig leaf of respectability. Wrong arguments made with a straight face were sufficient to carry the day. Under traditional constitutional theory, strict in theory spelled fatal in fact; rational basis was the open sesame to constitutional vindication; and intermediate scrutiny created the occasional horse race. Huge portions of the constitutional struggle lay in the selection of the standard, not in the fine points of interpretation for any particular statute or clause.

The central challenge of mainstream constitutional theory was, and is, to explain why different levels of scrutiny were, and are, brought to different constitutional challenges. The constitutional text provides no clue to this enterprise. The commerce clause and the takings clause are not written in invisible ink. Similarly, the first amendment, at least as to political speech, and the equal protection clause, at least as to race, are not written in indelible ink. And whatever the comparative durability of different provisions, why bring different levels of scrutiny to different challenges made under the same constitutional provision? The single most important litmus test is, without question, the confidence that the Court shows toward the political processes of Congress and the states. When it thinks that all factions and interest groups are able to fend for themselves, the Court blesses the political process, and happily defers to legislative choices, piously noting the institutional limitations that preclude its second guessing the political branches of government. But when the Court perceives a flawed political process, in that it excludes or marginalizes certain groups, it will spring to action to nullify the imbalance. No one who has so much as glanced at the history of race relations in the United States prior to the Civil Rights Act of 1964 can deny the obvious appeal of linking rotten politics to heightened levels of constitutional review.
This simple insight, grossly misapplied, shores up the defense of the BRCA offered in self-conscious joint authorship between Justices Stevens and O'Connor, both of whom were, once, Republican appointments to the bench. Their decision starts out with a long lament of the corrupt influence money has on politics. Their joint decision treats the "sober minded" Elihu Root as the hero du jour for his progressive call to keep politics out of public life. They fear that the public will become quickly disillusioned with politics so long as powerful corporations, unions and individuals can use dollars to gain access to legislators. Congress (whose expertise in this area comes from constant practice) is regarded as capable of healing itself. To Justices Stevens and O'Connor, the BCRA does not simply edge over some imaginary constitutional bar. No, they believe it will stem the tide of influence that dominates the American political scheme, by plugging the loopholes under the original FECA.

There is something deeply troublesome about this whole scenario, which prompts the title to this short paper. The striking feature of the decision in McConnell is the thinness of its account of political life. The decision is content simply to announce that the record is "replete" with instances in which money has purchased access to the political scene. Justices Stevens and $\mathrm{O}^{\prime}$ Connor treat the common practice of giving to both political parties as evidence of the sad truth that the donors care solely about access to key legislators and are indifferent to any larger ideological commitments of the candidates and public officials to whom they contribute their funds. ${ }^{4}$ Missing from this account is any explanation as to why the rich and famous clamor for access to politicians in the first place. The simplest explanation for this lies in two simple facts. First, politicians have a good number of resources that they can sell to the highest bidder. Second, politicians have the means to extort resources from the individuals by threatening them with adverse legislation. The initial question, which is nowhere addressed in the Stevens/O'Connor opinion, is

4124 S. Ct. at 649. 
how it is that politicians obtain the power to do the bidding of special interests (against whom we should all rightly rail) in the first place.

The answer to this question lies in the problem of double deference. The initial round of deference is not connected with the short term activities within the political process, but rather with the larger question of what it is that legislators (aka politicians) should do in the first place. The second round of deference arises in part because of the Supreme Court itself, which, in its relaxation of the protection of property rights and economic liberties, has created an unnecessary increase in the opportunities for politicians to trade on their office. The first-best solution in these instances is not to regulate the flow of campaign funds directly, but to defuse the entire process by removing the possibility of extensive forms of property and economic regulation from the legislative plate in the first instance. Much of the source of difficulty in this area stems from such decisions as Euclid v. Ambler Power, ${ }^{5}$ insofar as it deals with zoning, and Nebbia v. New York, ${ }^{6}$ insofar as it deals with price controls. We are likely to do far better as a nation by rejoicing in the present toothless nature of campaign finance regulation on the one hand and by cutting out large chunks of the state power to regulate economic and social affairs on the other. Strong constitutional safeguards on both levels are better than the current situation which recognizes congressional (and state) dominance in both areas. If Congress has less to sell, the usual suitors will pay far less for access to its chambers. Let me first examine the irreducible element of politics in public life and then turn to the interconnection between state regulation of the economy and campaign finance reform.

\section{ON THE NECESSITY OF POLITICAL INTRIGUE}

Any analysis of campaign finance must begin with the sober recognition that no matter how political institutions are organized, interest groups will seek out elective officeholders with political power. Society turns to government to provide a set of collective goods that no set of voluntary transactions can provide.
As the general economic theory of public goods indicates, peace, good order, and social infrastructure cannot be efficiently supplied by voluntary markets because the ostensible benefits that they create must be given to all so long as they are given to one. Since they are nonexcludable, everyone has an incentive to freeload on the actions of others. ${ }^{7}$

Ordinary politics would be relatively tame if these so-called public goods were really "goods," by which I mean all individuals enjoyed the goods and all detested the public bads. If the only differences among individuals were on the intensity of their preferences, the task of governance would be to match benefits and costs, such that, ideally, each individual would receive a value from the public good greater than the taxes and other resources that he was required to contribute to it. With this happy scenario no public bads would ever be created: so long as all individuals attach the same "sign" to any given public expenditure, no one will lobby to spend resources for public "goods" shunned by all. The freeriding that remains should be capable of resolution in any society in which all individuals share a single fundamental conception of good and bad.

Unfortunately politics is difficult because public goods in the economic sense are not public goods in that decisions favored by some are opposed by others. Should the United States decide to intervene in some foreign conflict on the side of A or B? Should it build this or that dam? Should it put the street lamp on a corner where the light is welcomed by some citizens but proves an annoyance to others? Each of these quintessential public decisions, large and small, will please some individuals, aggrieve others, and leave some in between. The only open question is which individuals will fall into which class.

This skewed distribution of payoffs works itself back into the incentive structure of the various interest groups. If outcome $A$ is worth +1000 to one group and outcome B is worth -1000 , then group A members have a built in

\footnotetext{
5272 U.S. 365 (1926).

6291 U.S. 502 (1934).

${ }^{7}$ Mancur Olson, The Logic of Collective Action (1965).
} 
reason to spend private resources to push the public decision in their direction. Their opponents have the same motivations but opposite interests. This process can consume enough resources to make all outcomes inferior to doing nothing at all. Yet by the same token, there is a crude and approximate sense in which God favors the larger battalions, so that the groups that can amass larger resources may be more likely to advance some net social goods, assuming some single metric captures the gains and losses of all individuals.

One obvious way to influence outcomes is to change the mix of the political figures who make the critical choices. Greater resources are devoted to public elections as the overall stakes increase. There are, however, difficulties in executing this program because the election of a candidate does more than influence any single decision. Public officials vote on countless issues. It is therefore risky business to invest too many resources in a candidate who may support you on one issue but oppose you on the next. Those expenditures are of uncertain value because of the difficulty of figuring out which other interest groups will invest, positively or negatively, in a candidate whose election members of a single group either support or oppose. There is little doubt that, even in the absence of regulation, political actors who care deeply about single issues will choose to put more of their resources in groups that lobby the issue, rather than in electing candidates whom they hope will be more sympathetic to their cause. Viewed in this light, it makes perfect sense for corporations, unions and prominent individuals to secure access to key officials, precisely because they do not know the issues that will matter come the next term, but do want an audience to whom they can make their case, whatever the issue turns out to be.

At this point, we can be confident that the Supreme Court is correct insofar as it suggests that purchased access to key candidates will work itself through to "change legislative outcomes." 8 Big deal. Some showing that the legislative outcomes under the current porous regime are worse than those under this new regime is needed to bridge the gap. Here not a single word written by Justices Stevens or O'Connor tends to support that stronger result, and for good reason. First, they have no descriptive account as to how the influence works in any particular case. Nor is it easy to supply a description. Soft money contributions are only a fraction of the total revenues that are spent on political campaigns. The money spent by one group may well neutralize that spent by another. All soft money may well be dwarfed by the expenditures that independent pundits make about elections, including those who rail against the evils of soft money. The money that is spent could have beneficial consequences, by reducing the costs of investigation to Congress about the consequences of various forms of legislation. The huge consequences of political decisions don't disappear because of a soft money or issue ad ban. Resources will surely be redirected to other activities that could be better or worse than the ones that they displace. Yet the changes in strategies in response to the legislative behaviors are nowhere taken into account.

Second, Justices Stevens and O'Connor have no normative view whatsoever as to what counts as good or bad legislation. In dealing with the classical public choices, that view is the only proper approach to such things as what kind of war should (or should not) be waged in Iraq, and whether Taiwan should be treated as an independent sovereign. Unfortunately, however, we do know one point about the current situation which does point to a systematic bias. As Justice Scalia pointed out in his dissent, each and every prohibition found in the BCRA-surprise!-tends to favor incumbents who already enjoy the benefits of office over the outsiders who do not. ${ }^{9}$ The case is one in which the formal equivalence of regulation on insiders and outsiders is matched by a disparate impact. It takes no public choice genius to realize that all incumbents share a common desire to resist involuntary turnover in public office. Yet there is no explanation by the Court as to how the entrenchment of incumbents offers even the slightest assistance to democratic theory. As that is the case, then the usual rule on strict scrutiny as it applies to political speech should not be displaced by some ad hoc

\footnotetext{
8124 S. Ct. at 664.

${ }^{9}$ Id. at $720-21$.
} 
(intermediate?) standard of "closely drawn" scrutiny, whose sole function is to stifle facial challenges while holding out some nebulous promise to consider some as-applied challenge long after the basic system has taken hold. I conclude, therefore, that for decisions that do belong in the public space, the deference afforded by the Court counts as a major compromise of the traditional guarantees of freedom of speech. The reduction of available information from all sources, the high cost of administrative regulation and the skew that it places on political discourse should have sent the BCRA to an early and ignominious death. How ironic it is that the Supreme Court is prepared to defer to Congress on the regulation of free speech after its own expose' of the sorry system of electoral politics that selected its members!

\section{THE SECOND FORM OF DEFERENCE}

The sins of this new found judicial deference on matters of speech have been, to say the least, mightily compounded by a second, regrettable, form of deference that has long been a fixture in American constitutional law. Much of the lobbying in Congress does not take place with respect to the indisputable public functions of government. Rather, it is directed to the regulation of economic affairs broadly construed within the economy. Here of course its sorry description of congressional politics should have led the Supreme Court to look with suspicion on the endless scads of special interest legislation that pour forth from Congress and the states. But the usual bromides of congressional expertise and judicial incompetence have led to a wholesale judicial capitulation of oversight over regulation. The simplest way to make the basic point is to examine Justice Stevens's and O'Connor's example of the clever ruse that the milk industry used to amass hefty sums to aid Richard Nixon's reelection campaign in order to promote its case for minimum price supports. ${ }^{10}$ An organized raft of small contributions allowed the industry to evade the spending and disclosure limitations in the then applicable campaign regulation. Well they should, in light of the hefty difference between the competitive and monopoly (controlled) price.

On this issue, however, as opposed to the grand affairs of state, it is possible to issue a categorical denunciation of the legislation passed at the behest of the dairy industry. The monopoly situation reduces output, raises prices, undercuts consumer surplus and blocks new entry, all of which are cardinal economic sins. It is for that reason that the system of minimum price supports arguably would not have withstood scrutiny under the early doctrines that allowed Congress and the states to regulate prices only in those industries "affected with the public interest." 11 In its best meaning, the term meant that the state could regulate the maximum rates of a monopoly industry but could not prop up the minimum rates of a competitive industry. The former task is hard to discharge, and may well be counterproductive. But at least the ends are intelligible even if the means are uncertain. The latter task is costly and socially destructive, but in Nebbia $v$. New York, ${ }^{12}$ an otiose Supreme Court brushed aside all qualms about rate regulation and blessed New York's effort to prop up its dairy cartel.

This fundamental structural decision to allow Congress and the states to flip freely between competition and monopoly changes the political landscape by allowing the maneuvers that Justices $\mathrm{O}^{\prime}$ Connor and Stevens denounce. Once this new power is conferred upon the legislature, farmers on the one side and consumer groups on the other will descend on Washington and state capitals in order to state their case. There is now some new bauble that Congress can sell, and some cushy preference that Congress can threaten to remove, so that the level of political discretion translates into a greater opportunity for abuse and intrigue. Justice Stevens (who today never supports the constitutional protection of property rights) and Justice O'Connor (who sometimes does) could have done a far greater service to the cause of

\footnotetext{
10124 S. Ct. at $646-47$ n. 6.

11 The history is complex. For my account of the ambiguities, see Richard A. Epstein, Let the Shoemaker Stick to His Last: A Defense of the "Old" Public Health, 46 Perspectives in Biology and Medicine S. 138, S141-142 (2003). 12291 U.S. 502 (1934).
} 
campaign reform by taking this issue off the table by resurrecting the long-lost constitutional protection of economic liberties. They could have done the same thing for property rights. Thus, last term both voted in support of the Copyright Term Extension Act in Eldred $v$. United States, ${ }^{13}$ on the familiar ground that only Congress had the expertise to decide whether to extend copyrights for 20 years at the behest of the Disney Corporation and the Gershwin Estate in celebration of the late Sonny Bono, no less. Let the Court take a strong constitutional position against the giveaway of various public domain rights, and yet another congressional window is no longer open for business. Do the same with respect to the labor statutes, the antidiscrimination laws in employment, and across the board Congress will have fewer goodies to dispose of, and in consequence there will be less to fear and less to hope for from its operation. This system of regulation is far more effective than BCRA's controls of election finances, for once the doctrine of deference is out across the board, then all forms of influence are worth less. The BCRA treats only symptoms but ignores the underlying disease. It promises to shift the sources of political influence, but will do little to improve the overall situation. Severely circumscribing legislative power does more to lessen all types of political currency. It is no panacea because influence will remain a political given for those inevitably, indeed properly, public decisions that remain. But by narrowing the class of public issues, it becomes possible to return a greater measure of social control to ordinary people by limiting the power of Congress to meddle in the lives of its citizens. Now that's a campaign reform worth fighting for!

Address reprint requests to: Richard A. Epstein Law School University of Chicago 1111 East 60th Street Chicago, IL 60637

E-mail: repstein@uchicago.edu

13537 U.S. 186 (2003). 